MATEC Web of Conferences 47, 05003 (2016)

DOI: $10.1051 /$ matecconf/20164705003

(C) Owned by the authors, published by EDP Sciences, 2016

\title{
Physiochemicals and Heavy Metal Removal from Domestic Wastewater via Phycoremediation
}

\author{
Abdul Rafiq Ab Razak ${ }^{1, a}$, Norshuhaila Mohamed Sunar ${ }^{2}$ Nurul Azira Alias ${ }^{1}$, Paran Gani ${ }^{1}$ and Menega \\ Subramaniam ${ }^{1}$ \\ ${ }^{1}$ Faculty of Civil and Environmental Engineering, Universiti Tun Hussein Onn Malaysia, 86400 Parit Raja, Johor, \\ Malaysia \\ ${ }^{2}$ Faculty of Engineering Technology, Universiti Tun Hussein Onn Malaysia, 86400 Parit Raja, Johor, Malaysia
}

\begin{abstract}
The common sources of water pollution in Malaysia are domestic sewage and industrial waste. Therefore, domestic wastewater quality effluent should be improved before discharged through the outlets. The alternative method of treatment uses microalgae for water remediation which is known as phycoremediation was applied. This technique is to remove or reduce nutrients and harmful pollutants in domestic wastewater. Thus, objective of the present study is to bioremediate the physiochemical and heavy metal from domestic wastewater using freshwater green microalgae Botryococcus sp. A photobioreactor is used to treat the wastewater by employing the microalgae Botryococcus sp. as a vital part of the treatment system. The results show that several nutrients have been reduced successfully such as phosphate and total phosphorus of $100 \%$ removal, inorganic carbon of $99 \%$ removal, total carbon of $42 \%$ removal, and nitrate of $10 \%$. The most prominent heavy metal content that has been removed is Aluminium of $41 \%$. At the same time, the growth of microalgae Botryococcus sp. in this wastewater has achieved the maximum value at Day 4 with $2.58 \times 10^{5}$ cell $/ \mathrm{ml}$ only. These results show the potential of Botryococcus sp. cultivation as an alternative method to treat domestic wastewater and any other biotechnology works in the future.
\end{abstract}

\section{Introduction}

Wastewater treatment using microalgae is considered an environmentally sound approach to minimize the excessive nutrients and has been applied for almost 50 year ago in special reactors termed highrate ponds system[1]. However, dewatering and harvesting of microalgae is assumed high in term of operation cost, especially where a limit on suspended solid is imposed by law [2].

In addition, the chosen microalgae species to be used in wastewater treatment normally determined based on their robustness to survive in wastewater against excessive nutrients such as nitrogen and phosphorus [3]. To breed $1 \mathrm{~kg}$ algal biomass, it requires $1.8 \mathrm{~kg}$ of $\mathrm{CO}_{2}$ [4]. This requirement helps to solve greenhouse problem[5]. Microalgae can also reduce the contents of pollutant and toxic metal in wastewater called phycoremediation[6][7]. Remediation is commonly refer to an array of regulatory requirements, and also can be based on assessments of human health and ecological risks where no legislative standards exist [8].

\footnotetext{
${ }^{a}$ Corresponding author : rafiqrazak@yahoo.com
} 
Phycoremediation is a process of employing microalgae or macroalgae for improving wastewater quality which able to fix carbon dioxide by using photosynthesis process and to eliminate excess nutrients effectively at minimal cost of operation[9-11]. This sustainable technique had been applied and studied widely using different type of wastewater such as domestic wastewater, greywater, dairywater, piggery wastewater and textile wastewater [12]. Microalgae growth is able to remove phosphorus and nitrate while able to present itself as an alternative to avoid water contamination[13].

The quality determining factor of pollutants is coming from domestic wastewater composing three major elements which are carbon, nitrogen and phosphorus. This is due to the content of the wastewater has organic matter and human waste such as urine, garbage, food waste and other solid material[14]. Moreover, domestic wastewater also contain mixed of bacteria which can give serious impact on human health and environment if uncontrolled discharged happened [15]. Conventionally, physical, chemical and biological methods are used to remove contaminants from wastewater and in order to achieve different level of contaminants treatment in wastewater, individual wastewater treatment procedures are combined into variety systems [16].

Basically, higher BOD levels mean the water is at poor quality [17]. The term of microalgae refer to microscopic biological plant which unable to be seen by naked eyes without microscope, and categorized as eukaryotic and prokaryotic cyanobacteria [18]. Cultivation of microalgae on wastewater can absorb $\mathrm{CO} 2$ and release $\mathrm{O}_{2}$ in the air through photosynthesis process. On global scale, microalgae be able to produce up to $75 \%$ of oxygen [19]. Other than that, others advantageous of phycoremedition is potentially valuable biomass produced for bio-based product such as bio-fertilizer, biofuel feedstock, food supplement and pharmaceutical industry [15]. Therefore, objective of the present study is to reduce physiochemical and heavy metal elements from domestic wastewater using microalgae.

\section{Materials and Methods}

\subsection{Wastewater preparation}

The domestic wastewater sample was collected at Universiti Tun Hussein Onn Malaysia domestic wastewater treatment plant. This plant caters the domestic waste such as sewage and rain water effluent. It has 2 stages of wastewater treatment which are primary and secondary treatment. The sample is collected before it reaches primary treatment. The wastewater sample is preserved at a temperature less than $4^{0} \mathrm{C}$ prior to the experimental. The physic-chemical parameters $(\mathrm{Ph}$, dissolved oxygen (DO), biochemical oxygen demand (BOD), chemical oxygen demand (COD), total organic carbon (TOC), total carbon (TC), inorganic carbon (IC), total nitrogen (TN), nitrate, phosphate and total phosphorus) and heavy metal elements (zinc $(\mathrm{Zn})$, ferum $(\mathrm{Fe})$, cadmium $(\mathrm{Cd})$, copper $(\mathrm{Cu})$, aluminium $(\mathrm{Al})$, lead $(\mathrm{Pb})$ and manganese $(\mathrm{Mn})$ were tested immediately based on standard methods [20]. Before commence the experiment, wastewater was filtered using membrane filter 0.45 um pore size to remove other microorganism and suspended solid.

\subsection{Microalgae preparation}

Microalgae Botryococcus sp. has been prepared at the microbiological experimental, Botryococcus sp. was cultured and the stock was maintained in the bold basal medium (BBM) for 14 days. The inoculums were counted using haemocytometer and initial cell concentration $10^{3}$ cell/mL which is based on the standard method and examination of water and wastewater (2009) and was transferred to the treatment medium for phycoremediation process. 


\subsection{Experimental set-up}

The pre-treated domestic wastewater was poured into a photobioreactor which can hold about $17 \mathrm{~L}$ of water sample with aeration provided at $1 \mathrm{~L} / \mathrm{min}$ to homogenize the wastewater and microalgae during phycoremediation. After that, the sample was inculated with the microalgae seed at inoculum of $1.0 \mathrm{x}$ $10^{3} \mathrm{cell} / \mathrm{ml}$ and the cell count was performed using haemocytometer with the help of light compound microscope according to standard method [21]. The phycoremediation was done for 20 days under outdoor natural conditions.

\section{Results and Discussion}

\subsection{Characteristic of wastewater}

These parameters are important for next analysis which is analysis for physiochemical and heavy metal after phycoremediation process. The parameter chosen has shown at Table 1 below with the wastewater sample and compared the value with Standard A and Standard B of Malaysia Wastewater Effluent Discharge (2000) guidelines.

Table 1. The raw characteristic for wastewater sample $(n=3)$.

\begin{tabular}{|l|c|c|c|}
\hline \multirow{2}{*}{ Physiochemical } & \multirow{2}{*}{$\begin{array}{c}\text { Domestic } \\
\text { wastewater }\end{array}$} & \multicolumn{2}{c|}{$\begin{array}{c}\text { Malaysia Wastewater Effluent } \\
\text { Discharge Standard (2000) }\end{array}$} \\
\cline { 3 - 4 } & & A & B \\
\hline Chemical oxygen demand (mg/L) & 34 & 50 & 100 \\
\hline Biochemical oxygen demand (mg/L) & 93 & 20 & 50 \\
\hline Total phosphorus (mg/L) & 3.3 & - & - \\
\hline Total nitrogen (mg/L) & 15.79 & - & - \\
\hline Total suspended solid (mg/L) & 2267 & 50 & 100 \\
\hline Total dissolved solid (mg/L) & 12600 & - & - \\
\hline Total organic carbon $(\mathrm{mg} / \mathrm{L})$ & 5.53 & - & - \\
\hline Total carbon $(\mathrm{mg} / \mathrm{L})$ & 24.39 & - & - \\
\hline Inorganic carbon $(\mathrm{mg} / \mathrm{L})$ & 18.86 & - & - \\
\hline Nitrate $(\mathrm{mg} / \mathrm{L})$ & 3.12 & - & - \\
\hline Phosphate $(\mathrm{mg} / \mathrm{L})$ & 267.49 & - & - \\
\hline Dissolved oxygen $(\mathrm{mg} / \mathrm{L})$ & 10.91 & - & $5.5-9.0$ \\
\hline pH & 2.5 & $6.0-9.0$ & - \\
\hline Turbidity $(\mathrm{mg} / \mathrm{L})$ & 38 & - & \\
\hline
\end{tabular}

Table 2. The heavy metal characteristic for wastewater sample $(n=3)$.

\begin{tabular}{|c|c|c|c|c|c|c|c|}
\hline $\begin{array}{c}\text { Heavy } \\
\text { metal }\end{array}$ & $\begin{array}{c}\text { Zinc, } \\
\mathbf{m g} / \mathbf{L}\end{array}$ & $\begin{array}{c}\text { Ferum, } \\
\mathbf{m g} / \mathbf{L}\end{array}$ & $\begin{array}{c}\text { Cadmium, } \\
\mathbf{m g} / \mathbf{L}\end{array}$ & $\begin{array}{c}\text { Copper, } \\
\mathbf{m g} / \mathbf{L}\end{array}$ & $\begin{array}{c}\text { Lead, } \\
\mathbf{m g} / \mathbf{L}\end{array}$ & $\begin{array}{c}\text { Aluminium, } \\
\mathbf{m g} / \mathbf{L}\end{array}$ & $\begin{array}{c}\text { Manganese, } \\
\mathbf{m g} / \mathbf{L}\end{array}$ \\
\hline $\begin{array}{l}\text { Domestic } \\
\text { wastewater }\end{array}$ & 0.662 & 0.907 & 0.0008 & 0.0132 & 0.447 & 0.0062 & 0.342 \\
\hline Standard A & 1.0 & 1.0 & 0.01 & 0.2 & 10 & 0.1 & 0.2 \\
\hline Standard B & 1.0 & 5.0 & 0.02 & 0.1 & 15 & 0.05 & 1.0 \\
\hline
\end{tabular}

\subsection{Removal of physiochemical properties}

Phosphate, nitrate, TC, TOC, IC and TC classified as a nutrient in wastewater. The analysis has measured all the parameter proved the nutrient content can be treated effectively by Botryococcus sp. According to the Figure 1, the most effective nutrient removal are total phosphorus and phosphate with $100 \%$ removal from Day 4 until Day 20 followed by inorganic carbon with $83.4 \%$ at Day 4 


\section{MATEC Web of Conferences}

increase to $99.9 \%$ at Day 20. However, the value of total carbon removal is $73.1 \%$ at Day 4 decrease to $42.6 \%$ at Day 20. Phosphorus has been removed fully as microalgae uses phosphorus and nitrate for its growth[1]. The nitrate value also reduces from $95.2 \%$ to $10.1 \%$ at the last day. Botryococcus sp. consumes nitrogen quickly in ammonium form [22]. The conclusion is both of these nutrients had been removed after treatment using microalgae (Botryococcus sp.).

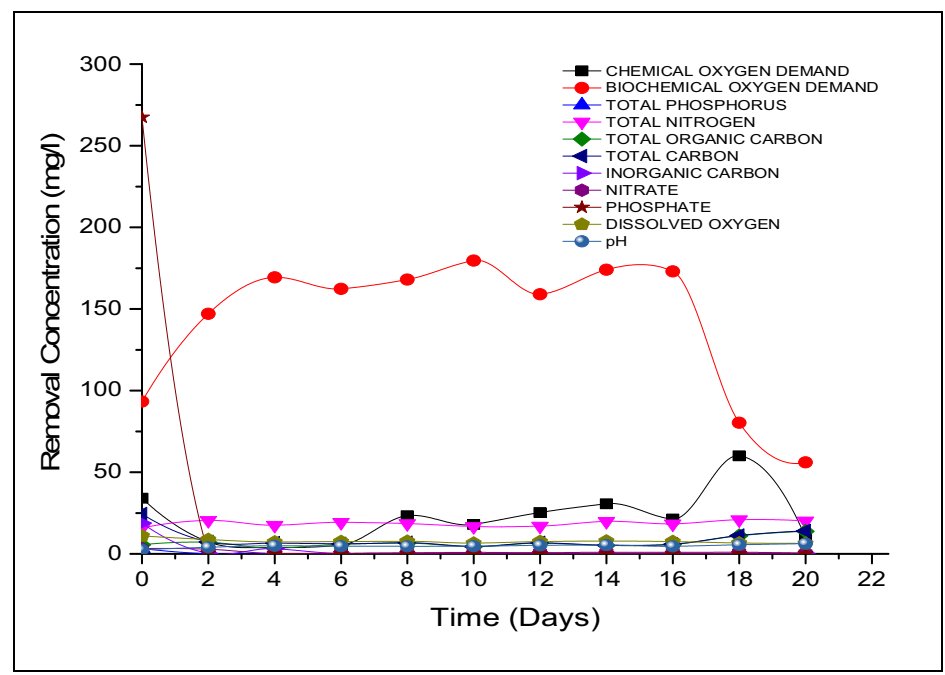

Figure 1. The nutrients removal for domestic wastewater during phycoremediation.

\subsection{Removal of heavy metal properties}

The highest removal of heavy metal at the end of research is ferum. However, after 20 days the higher value is still zinc and the lower value is cadmium. Some of the elements are not effectively removed from wastewater because the result does not achieve Standard of Malaysian Effluents Guidelines. The conclusion is aluminium value can be acceptable for the standard guideline which is the one and only heavy metal in domestic wastewater that can be treated by using microalgae (Botryococcus sp.).

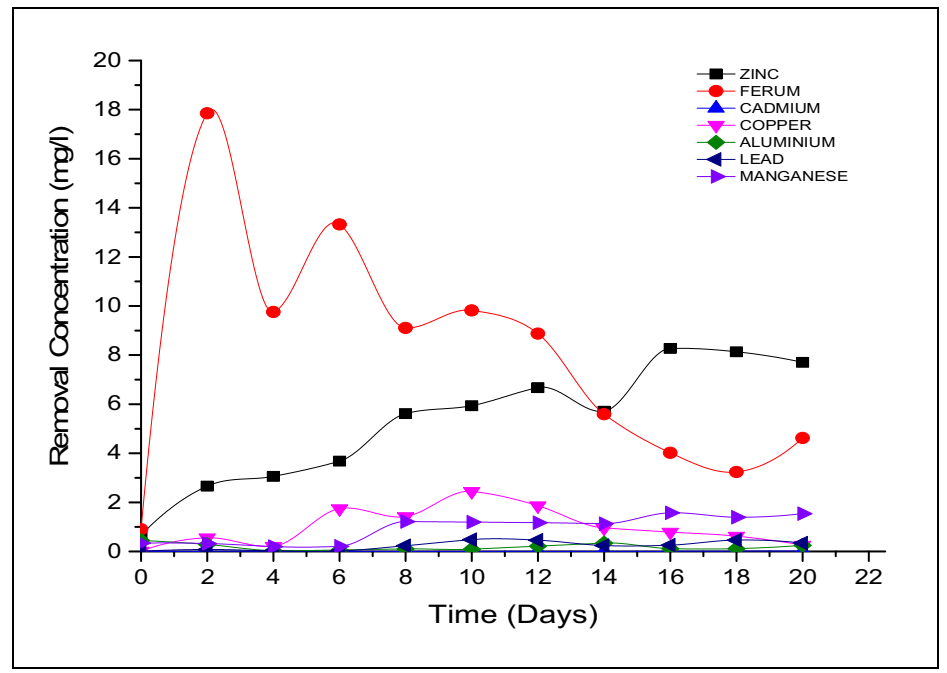

Figure 2.Graph of heavy metal in domestic wastewater during phycoremediation. 


\section{Conclusions}

The growth of microalgae Botryococcus sp. in domestic wastewater has been achieved the maximum value at Day 4 with $2.58 \times 105$ cell $/ \mathrm{ml}$. The nutrients had been removed at the domestic wastewaters which are phosphate, total phosphorus, inorganic carbon, total carbon and nitrate. The heavy metal shows high removal efficiency using phycoremediation. This study needs to be explored to unveil its potential. It is recommended that more studies be carried out to investigate the retention time required to efficiently treat the wastewater.

\section{Acknowledgements}

The authors would like to acknowledge Research and Innovation Centre (R\&D) Research, Innovation, Commercialization and Consultancy Office (ORICC) Universiti Tun Hussein Onn Malaysia for funding this project under grant FRGS vot 1479.

\section{References}

[1] N. Abdel-Raouf, A.A. Al-Homaidan and I.B.M. Ibraheem, Microalgae and wastewater treatment, Saudi J. Biol. Sci., 19( 3), 257-275, (2012).

[2] J. Shi, B. Podola and M. Melkonian, Removal of nitrogen and phosphorus from wastewater using microalgae immobilized on twin layers: An experimental study, J. Appl. Phycol., 19(5), 417-423, (2007).

[3] H.Azarpira, P. Behdarvand, K. Dhumal and G. Pondhe, Potential use of cyanobacteria species in phycoremediation of municipal wastewater, Int. J. of Biosciences, 4(4), 105-111, (2014).

[4] U. Emeka, G.I. Ndukwe, K.B. Mustapha and R.I. Ayo, Constraints to large scale algae biomass production and utilization, J. of Algal Biomass Utilization, 3(2), 14-32, (2012).

[5] F.M. Salih, Microalgae tolerance to high concentrations of carbon dioxide: A review, J. Environ. Prot., 2(5), 648-654, (2011).

[6] P.H. Rao, R.R. Kumar, B. Raghavan, V. Subramanian and V. Sivasubramanian, Application of phycoremediation technology in the treatment of wastewater from a leather-processing chemical manufacturing facility, Water SA, 37(1), 7-14, (2011).

[7] P. Gani, N.M. Sunar, A.A.A. Latiff, I.T.K. Joo, U.K. Parjo, Q. Emparan and C.M. Er, Phycoremediation of dairy wastewater by using green microlgae: Botryococcus sp., Appl. Mech. Mater., 773-774, 1318-1323, (2015).

[8] J. Chotwattanasak and U. Puetpaiboon, Full scale anaerobic digester for treating palm oil mill wastewater, J. Sustain. Energy Environ., 2(3), 133-136, (2013).

[9] P.O. Souza, L.R. Ferreira, N.R.X. Pires, P.J.S. Filho, F.A. Duarte, C.M.P. Pereira and M.F. Mesko, Algae of economic importance that accumulate cadmium and lead: A review, Brazilian J. Pharmacogn., 22(4), 825-837, (2012).

[10] S. Chinnasamy, A. Bhatnagar, R.W. Hunt and K.C. Das, Microalgae cultivation in a wastewater dominated by carpet mill effluents for biofuel applications, Bioresour. Technol., 101(9), 30973105, (2010).

[11]P. Gani, N.M. Sunar, H. Matias-Peralta, A.A.A. Latiff, U. Kalthsom, A. Rafiq and A. Razak, Phycoremediation of wastewaters and potential hydrocarbon from microalgae: A review, Adv. Environ. Biol., 9(20), 1-8, (2015).

[12]S. Elumalai, S. Ramganesh and T. Sangeetha, Phycoremediation for leather industrial effluent treatment and recycling using green microalgae and its consortia, Int. J. of Current Phycoremediation, 2(10), 1-9, (2014).

[13]P. Gani, N.M. Sunar, A.A.A Latiff, N.S. Kamaludin, U.K. Parjo, Q. Emparan and C.M. Er, Experimental study for phycoremediation of Botryococcus sp . on greywater, Appl. Mech. Mater., 773-774, 1312-1317, (2015). 


\section{MATEC Web of Conferences}

[14]M.A. Fulazzaky, Carbonaceous, nitrogenous and phosphorus matters removal from domestic wastewater by an activated sludge reactor of nitrification-denitrification type, J. Eng. Sci. Technol., 4(1), 69-80, (2009).

[15]H. Kamyab, M. Soltani, M. Ponraj, M.F. Din and E.V. Putri, A review on microalgae as potential lipid container with wastewater treating functions, J. of Environmental Treatment Techniques, 1(2), 76-80, (2013).

[16]A.L.A. Zinatizadeh, Biological treatment of palm oil mill effluent (Pome) using an up-flow anaerobic sludge fixed film (Uasff) bioreactor, PhD Thesis, Universiti Sains Malaysia, Penang, (2006).

[17]J.R. Votano, M. Parham, L.H. Hall, L.B. Kier and L.M. Hall, Microalgae: The green gold of the future?, Chem. Biodivers., 1(11), 1829-1841, (2004).

[18]P. Metzger and C. Largeau, Botryococcus braunii: A rich source for hydrocarbons and related ether lipids, Appl. Microbiol. Biotechnol., 66(5), 486-496, (2005).

[19]Z. Yaakob, K.F. Kamarudin and R. Rajkumar, The Current Methods for the biomass production of the microalgae from wastewaters: An overview, World Applied Sciences J., 31(10), 17441758, (2014).

[20]APHA, AWWA, and WEF, Standard Methods for the Examination of Water and Wastewater, American Public Health Association, American Water Works Association and Water Environment Federation, (2005).

[21] O. Bastidas, Cell counting with neubauer chamber (basic hemocytometer usage), Technical Note - Neubauer Chamber Cell Counting, Celeromics, (2014).

[22]R. Órpez, M.E. Martínez, G. Hodaifa, F. El-Yousfi, N. Jbari and S. Sánchez, Growth of the microalga botryococcus braunii in secondarily treated sewage, Desalination, 246(1), 625-630, (2009). 